\title{
Water Security in Green Campus Assessment Standard
}

\author{
Mia Wimala ${ }^{1}$, Bob Zirads ${ }^{2}$, and Rindu Evelina ${ }^{2}$ \\ ${ }^{1}$ Department of Civil Engineering, Universitas Katolik Parahyangan, Jl. Ciumbuleuit 94, Bandung 40141 Indonesia \\ ${ }^{2}$ Department of Civil Engineering, Institut Teknologi Nasional, Jl. P.H.H. Mustofa 23, Bandung 40124 Indonesia
}

\begin{abstract}
The importance of fresh water in human life entails people to be conscious of conserving the resources since only one percent of the total fresh water on the earth is easily accessible. Green campus is a concept implemented by campuses where policies are lead to ecological points of view. This research aims to update the UI GreenMetric standard, focusing on Water (WA) category as a recommendation for Universitas Indonesia as the initiator. Referrals from other related standards, i.e. STARS ${ }^{\circledR}$ and Greenship were done on developing the category with its contents. Furthermore, the re-weighting and re-scoring system of the newly developed category were carried out using Analytical Hierarchy Process method, adjusted to the existing laws/regulations in Indonesia. For verification purposes, a study on campus performance at Universitas Katolik Parahyangan, was conducted using the newly developed category. The proposed strategies were then set to improve the campus performance in the future.
\end{abstract}

\section{Introduction}

Water is essential for human's daily life. While nearly $70 \%$ of the world is covered by water, only less than $3 \%$ of it is fresh water [1]. Even then, only less than $1 \%$ of the earth's water is easily accessible, since the rest are still trapped in icebergs and glaciers [2]. Along with the dramatic growth of Earth's populations, the need for fresh water also tends to increase sharply. This causes an imbalance between the water supply and demand. According to the United Nations, people globally tend to use the water at twice the rate of population increase in the last century [3]. It is projected that by $2025,1.8$ billion people will face absolute water scarcity, and twothirds of the world population could be under water stress conditions [4]. The challenge to be faced as we head to the future is to find ways to conserve, manage, distribute, and use the existing water effectively.

Green campus is a holistic approach that is increasingly applied to many universities in the world nowadays with the aim of raising environmental awareness, so that each individual can then implement it as an intrinsic part of everyday life activities. The benefits of green campus implementation have been studied over the past few decades from an environmental, social and economy point of view. Among others are: energy savings, GHG emissions reduction, less operational and maintenance cost, higher work productivity, improved health and safety, increased research grants and collaborations among institutions/corporates, and rising employment [5].

UI GreenMetric-World University Ranking, a green campus rating tool was first established in 2010 by Universitas Indonesia (UI) to measure the campus green performance. Despite the fact that it has been developed over the past seven years, UI GreenMetric still needs to be constantly updated to address the shortcomings and keep up with the latest trends of sustainable issues. Therefore, this research aims to point out some performance indicators that are still left behind to be considered in UI GreenMetric, focusing on Water (WR) category based on a literature review of two similar standards, i.e. Sustainability Tracking, Assessment and Rating System $\left(\right.$ STARS $\left.^{\circledR}\right)$, and Greenship. New recommended subcategories, indicators, and subindicators, along with their re-weighting and re-scoring system are proposed for future improvement.

\section{Green Campus}

\subsection{Green campus assessment}

Green campus rating tool aims to rank and reward each level of effort towards sustainability by a higher education institution in accordance with predetermined requirements. As of today, each institution has the right to choose the rating system it will pursue; especially in Indonesia where there are no regulation that limits the participation of an institution in the existing green campus rating tools all around the world.

The rating can be done either by first, second or third party. However, a third-party assessment that is usually conducted by an independent party, such as the UI GreenMetric or STARS ${ }^{\circledR}$, who has no ties to the outcome of the assessment, is considered to be more reliable. Although an institution does not necessarily need to have the green campus ranking or certification, third-party recognition adds credibility to the institution for all the efforts performed. 


\subsection{Water category in green assessment standard}

UI GreenMetric was established based on an environmental sustainability concept, encompassing the aspects of the Environment, Economy and Equity (3'Es) [6]. Rested upon each performance achievement, the purpose of the ranking is to encourage higher education institutions worldwide to pay attention and self-assess their efforts done to support the sustainability development. The rank will be used not only to monitor the performance of each institution, but also of that among other institutions all around the world for benchmarking purposes. It will also affect many factors, such as further decision-making related to sustainability efforts, institution branding, networking, quality of education, research, and community engagement programs.

According to Rector UI, Prof. Muhammad Anis, UI GreenMetric has been recognized worldwide and officially accepted as a member by Ranking Expert Group (IREG) Observatory [7]. In 2017, 619 universities from 76 countries in the world have participated and used the performance indicators developed by UI GreenMetric [6], and $9.2 \%$ of those are from Indonesia. Setting and Infrastructure (SI), Energy and Climate Change (EC), Waste (WS), Water (WR), Transportation (TR), and Education (ED) are six categories that are taken into account in the assessment of UI GreenMetric. An increase in the number of indicators has occurred since the first UI GreenMetric was released in 2010: 23 indicators to 38 indicators in the latest version that was issued in 2015 [8]. The participants are further ranked based on the maximum and minimum scores, according to the climate of each institution's location.

Greenship is a green building standard in Indonesia issued by Green Building Council Indonesia (GBCI). This standard is developed with the aim to disseminate to the communities and construction stakeholders the importance of adopting green building concepts in Indonesia. Meanwhile, regardless of its function as an assessment standard for green building, and not for green campus, Greenship was used as a reference in this research because of the common laws/regulations regarding water issues that are commonly used in Indonesia. Based on Greenship, a green building must meet the requirements points for the six categories consisting of Appropriate Site Development (ASD), Energy Efficiency and Conservation (EEC), Water Conservation (WC), Material Resources and Cycle (MRC), Indoor Air Health and Comfort (IHC), and Building and Environment Management (BEM). Currently, Greenship is classified into five types, namely standard for New Building, Existing Building, Interior Space, Homes and Neighborhood. Each type of Greenship can then be ranked into Platinum, Gold, Silver and Bronze.

The United States of America is one of the pioneers in green building, as well as green campus implementation. The Association for the Advancement of Sustainability in Higher Education (AASHE), an association that committed to encourage and support the advancement of sustainability in higher education has successfully launched STARS ${ }^{\circledR}$ in 2010. It is developed as a voluntary, self-reporting framework to helping colleges and universities track and measure their sustainability progress [9]. STARS was chosen as one of the reference standards because of its extensive depth of assessment and application. Since it was first launched, STARS ${ }^{\circledR}$ has been updated six times, including the pilot versions incorporating feedback, suggestions, and lessons learned from the previous versions. There are 17 performance indicators and $63 \mathrm{sub}$-indicators organized into four main criteria, i.e. Academics (AC), Engagement (EN), Operations (OP), and Planning and Administration (PA), and one bonus criteria, i.e. Innovation and Leadership (IN) with two performance indicators that need to be met by a green campus. Similar to Greenship, the institution will be rated according to points earned for all efforts that have been made, ranging from a STARS ${ }^{\circledR}$ Bronze with minimum score of 25, Silver with 45 , Gold with 65 or Platinum with 85. Any institution is allowed to participate in STARS $^{\circledR}$ and submit the data publicly without pursuing a green campus rating, and will earn recognition as a STARS ${ }^{\circledR}$ Reporter. Established in 2005, STARS $^{\circledR}$ is now used by over than 900 members from 37 countries.

Table 1 shows the subcategories related to water category, as the main topic in this research, taking into account their similarities, based on UI GreenMetric, Greenship, and STARS ${ }^{\circledR}$.

Table 1. Water category of each standard.

\begin{tabular}{|c|l|}
\hline Standard & \multicolumn{1}{|c|}{ Subcategory } \\
\hline \multirow{2}{*}{ UI } & - Water Conservation (WR1) \\
GreenMetric & - Water Recycling Program (WR2) \\
& - Water Efficient Appliances Usage (WR3) \\
& - Treated Water Consumed (WR4) \\
\hline & - Water Management Policy (WAC P) \\
& - Water Sub - Metering (WAC1) \\
& - Water Monitoring Control (WAC2) \\
Greenship & - Fresh Water Efficiency (WAC3) \\
(for Existing & - Water Quality (WAC4) \\
Buildings) & - Recycled and Alternative Water (WAC5) \\
& - Potable Water (WAC6) \\
& - Deep Well Reduction (WAC7) \\
& - Water Tap Efficiency (WAC8 - Bonus) \\
\hline STARS & - Water Use (OP26) \\
& - Rainwater Management (OP23) \\
\hline
\end{tabular}

(GreenMetric, 2017; Greenship, 2017; STARS, 2017)

\section{Research Methodology}

The research began with a literature review on green campus concepts, existing standards, rating tools and certification systems, as well as case studies of green campus implementation worldwide. More readings were continued to collect secondary data which mostly focused on the performance indicators of UI GreenMetric, Greenship, and STARS $^{\circledR} \quad$ v.2.1. Semi-structured 
interviews with the teams from all rating tools were also conducted. It is further continued with comparative analysis to generate some recommended indicators that should be considered into UI GreenMetric for future improvement, particularly those considered under Indonesian circumstances.

Using qualitative descriptive method, the development of new indicators within the Water (WR) category is determined based on the consideration of existing conditions at higher education institutions all around the world. Once validated, this newly developed category, along with its subcategories, indicators, and subindicators were re-weighted using Analytical Hierarchy Process (AHP) method. This method utilizes the feedback of several experts, consisting of lecturers and practitioners, who are scattered in the fields of environmental engineering, water resources engineering, hydraulic engineering, stream restoration and river mechanics, water engineering and technology, and sustainability in general. Some of the experts even hold the Greenship Associate (GA) and Greenship Professional (GP) certification from Green Building Council Indonesia (GBCI) as green building assessors. The next step was building the re-scoring system, following the current laws/regulations regarding water issues in Indonesia, and in part, based on expert opinions.

The new developed category, named as Water Security (WS) was further piloted in a case study, at Universitas Katolik Parahyangan (Unpar) for verification purpose.

\section{Results}

\subsection{Water Security (WS)}

The new category, i.e. Water Security (WS) was developed based on consideration of several factors such as laws/regulations in Indonesia as the initiator country, weather, climate and environmental condition, existing campus condition worldwide, expert opinions in related fields, and potential use throughout the globe. The category classifies three subcategories consisting of: Water Use, Conservation and Efficiency (WUCE), Waste Water Treatment (WT), and Water Quality (WQ), along with its indicators and sub indicators as written on Table 2 .

Table 2. New category - Water Security (WS).

\begin{tabular}{|c|c|}
\hline Subcategory & Indicator \\
\hline $\begin{array}{c}\text { Water Use, } \\
\text { Conservation, and } \\
\text { Efficiency } \\
\text { (WUCE) }\end{array}$ & $\begin{array}{l}\text { - Water Policy } \\
\text { - Water Campaign } \\
\text { - Water Use, Conservation and } \\
\text { Efficiency Practices } \\
\text { - Monitoring of Use and Water Leaks } \\
\text { - Water Equipment Efficiency } \\
\text { - Alternative/Recycled Water } \\
\text { Resources }\end{array}$ \\
\hline $\begin{array}{c}\text { Wastewater } \\
\text { Treatment (WT) }\end{array}$ & - Wastewater Management Authority \\
\hline $\begin{array}{l}\text { Water Quality } \\
\text { (WQ) }\end{array}$ & - Non Potable Water \\
\hline
\end{tabular}

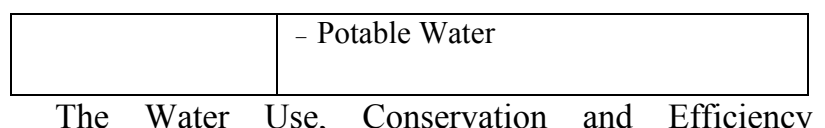

(WUCE) subcategory prioritizes prevention efforts aimed at reducing general water use, i.e. potable and clean water. It is intended to help replenishing natural aquifers, reduce erosion impacts, decrease pressures on public infrastructure and minimize local water contamination. Although both terms are often interpreted equally, water conservation and efficiency has a fundamental difference. Water conservation is protection from water loss. Therefore, water conservation can be translated into a variety of activities, ranging from policy arrangements to the planning of green practice programs for students and staff to use less water. Water efficiency, on the other hand, is emphasized towards changing habits and behavior of students and staffs with the help of innovative and smart technology to minimize the amount of water used to accomplish a function, task, or result. It will directly result in energy and operational cost savings. Six indicators included in this subcategory are Water Policy and Standard Operating Procedure, Water Campaign, Water Use, Conservation and Efficiency Practices, Monitoring of Use and Water Leaks, Water Appliances Efficiency, and Alternative/Recycled Water Resources.

The Wastewater Treatment (WT) subcategory is considered in green campus assessment due to laboratory facilities that generally produce liquid waste, which require special handling and treatment in its disposal. The wastewater management authority is the only indicator assessed in this subcategory.

In Indonesia, water can be obtained through public sources that are managed by the government, as well as through private ground water sources. It is difficult to ensure the water quality from individual or communal sources. However, the quality assurance of water in public places, i.e. campus, especially the potable water, should be carefully observed. The purpose is ensuring the health of students and staffs through daily consumption of quality water. Due to the importance of water quality used in daily activities, Water Quality (WQ) subcategory is therefore added to this assessment. The requirements of water quality, translated as indicators and sub-indicators, were established according to Regulation of the Minister of Health of the Republic of Indonesia No.416/MENKES/PER/IX/1990 on the Requirements and Water Quality Control, and Regulation of the Minister of Health of the Republic of Indonesia No.492/MENKES/PER/IV/2010 on Drinking Water Quality Requirements.

\subsection{Weights and scoring system}

Due to the modification of the Water (WR) category of the UI GreenMetric, it is necessary to re-weight and rescore the newly developed category in order to be used in green campus assessment. The result of re-weighting and re-scoring each level of subcategories, indicators and subindicators, as shown in Table 3, column (1), (2), and (4). 
Water Use, Conservation and Efficiency (WUCE) category weighs relatively larger than the other two categories. This is due to long-term positive impact on the quantity and quality of water in general as a result of the efforts undertaken. Two indicators that have each relatively large weight in them are Alternative/Recycled Water Resources, and Water Use, Conservation and Efficiency Practices. Indicator of Alternative/Recycled Water Resources with an assessment weight of 0.27 is intended to increase the awareness of supporting facilities such as rainwater tanks, and water treatment plants. Meanwhile, Water Use, Conservation and Efficiency Practices indicator is directed more to green infrastructure aimed at reducing surface runoff caused by the absence of rainwater into the soil and results in large volume of water in the drainage system. With the increase of water catchment areas and rainwater harvesting, it is expected to reduce the use of drainage system and allow the water to be infiltrated into the soil.

\subsection{Case study}

The object studied in this research was conducted at Universitas Katolik Parahyangan (Unpar), Indonesia. The data required in assessing the green performance of Unpar in Water Security (WS) were obtained mostly through semi-structured interviews with the Building Maintenance Department Manager, as well as supervisors and other personnel. The data was then verified through site observations to obtain visual and in-depth assessment.

Assessment were done based on 5 categories ranging from Very Low to Very High, with a range of 20 points for each category. The results of the existing green performance assessment at Unpar can be formulated in Table 3. Column (5) in Table 3 shows the green performance of Unpar obtained by interview and site observation. As written in Table 3 Column (6), Unpar managed to get a score of 82.21 points, out of a total of 122 , which was denoted into the Good category.

\subsection{Discussions}

Regardless of the outcome, there are some issues that need to be addressed to improve the future performance. Among others are:

a. Apart from its current implementation, the water campaign has not been delivered well, both in terms of quality and quantity. The observations indicate that the approaches are still in the form of common appeals. It is necessary to consider the consequence/fear appeals in the future, as well as the practice of reward/punishment system to raise awareness of the campus community. Various media owned by Unpar such as Unpar radio station, digital information board, and social media should also be used up to the maximum to disseminate the necessary information.

b. Unpar has followed the local regulation concerning water conservation contained in Keputusan Kepala Dinas Penanaman Modal dan Pelayanan Terpadu
Satu Pintu Provinsi Jawa Barat tentang Perpanjangan Air Tanah Universitas Katolik Parahyangan. The document describes the obligations that must be done by Unpar as compensation for the use of ground water to the environment.

- Unpar already has 3 infiltration wells with dimensions of $1 \mathrm{~m}$ in diameter and $3 \mathrm{~m}$ depth. Nevertheless, up to now, the existing infiltration wells only serve as a rainwater harvesting system. To ensure its effectiveness, the rainwater should be used further by Unpar in the future, either for garden watering, toilet flushing, or vehicle washing.

- Unpar could increase the area of existing roof garden at this time of $1,734 \mathrm{~m}^{2}$ in some other areas that have not implemented this practice. The same thing could be done in relation to the use of permeable pavement, urban tree canopies, green streets, and green alley. Unpar may consider to extend them to outside areas around the campus.

c. In order to control water usage, it is recommended that an extra water meter is installed at each building in campus area.

d. Maintenance activities, both prevention and improvement of existing water fixtures are expected to be more planned, organized and fast-respond.

e. Regardless of the large amount of energy-efficient water appliances, which is more than $75 \%$, used by Unpar at the moment, the use of automation and sensor taps could be considered in the future to achieve maximum results.

f. At present, the wastewater is handled entirely by the $3^{\text {rd }}$ party i.e. Integrated Service Solutions (ISS) due to the need of professionals in handling hazardous and toxic materials waste (B3). However, Unpar should try to sort out which handling methods/procedures could be self-managed, and prepare the personnel through proper training to be involved in similar cases in order to reduce operational costs.

g. A water purification facility has been installed by Unpar inside the campus to meet the drinking water needs of the students and staff. The water has been tested and the results have met the existing standards in Indonesia. Tests including physical, chemical and bacteriological were performed periodically. However, there are a few issues that need to be fixed such as the condition of water faucets at the facility, and how it was used. The hygiene level still needs to be improved, and in terms of the way it is used, the students and staff should be informed in detail how to use the facility in the correct way to avoid wear damage.

h. Due to illegal use of water by outsiders, the pipelines within the campus must be kept more stringent. 
Table 3. Water Security Assessment Standard and Its Application at Universitas Katolik Parahyangan

\begin{tabular}{|c|c|c|c|c|c|}
\hline Subcategory & Indicator & Sub Indicator & $\begin{array}{l}\text { Scoring Factor } \\
\text { of } S \text { ub Indicator }\end{array}$ & $\begin{array}{c}\text { Point } \\
\text { Earned } \\
\end{array}$ & Total Point \\
\hline [1] & [2] & [3] & {$[4]$} & {$[5]$} & {$[6]=\Sigma[5] \times[2] \times[1]$} \\
\hline \multirow{29}{*}{$\begin{array}{l}\text { Water Use, } \\
\text { Conservation and } \\
\text { Efficiency } \\
\text { (WUCE) } \\
56.40 \%\end{array}$} & \multirow[t]{3}{*}{1 Water Policy $(10.50 \%)$} & \multicolumn{3}{|c|}{$\begin{array}{l}\text { Institutional policies in a form of Standard Operational Procedure (SOP)/designation } \\
\text { letter/management team or work personnel establishment }\end{array}$} & \multirow{3}{*}{5.92} \\
\hline & & 1 None & 0 & 0 & \\
\hline & & 2 Available & 100 & 100 & \\
\hline & \multirow[t]{3}{*}{2 Water Campaign $(7.70 \%)$} & \multicolumn{3}{|c|}{ Campaign through email, sticker, banner, poster, slogan, website, radio and various social media } & \multirow{3}{*}{4.34} \\
\hline & & 1 None & 0 & 0 & \\
\hline & & 2 Available & 100 & 100 & \\
\hline & \multirow{6}{*}{$\begin{array}{l}3 \text { Water Use, Conservation, } \\
\text { and Efficiency Practices } \\
(23.30 \%)\end{array}$} & \multicolumn{3}{|l|}{ Please select one or more from the following practices: } & \multirow{6}{*}{10.49} \\
\hline & & 1 Biopori Holes/Infiltration Wells/Ground Water Tanks & 11.16 & 11.16 & \\
\hline & & 2 Rain Harvesting System//Roof Gardens/Bioswales & 34.32 & 34.32 & \\
\hline & & 3 Permeable Pavements & 19.58 & 19.58 & \\
\hline & & 4 Lakes/Ponds & 19.83 & 0 & \\
\hline & & $\begin{array}{l}5 \text { Landscaping/Revegetation/Urban Tree Canopies/Green Street } \\
\text { and Alleys }\end{array}$ & 15.11 & 15.11 & \\
\hline & \multirow{7}{*}{$\begin{array}{l}4 \text { Monitoring of Use and } \\
\text { Water Leaks }(12.10 \%)\end{array}$} & \multicolumn{3}{|l|}{\begin{tabular}{|l|} 
Water meter installation. Please select one or more options: \\
\end{tabular}} & \multirow{3}{*}{0.58} \\
\hline & & 1 Main water meter & 8.44 & 8.44 & \\
\hline & & 2 Extra water meter at each building & 30.04 & 0 & \\
\hline & & \multicolumn{3}{|c|}{ Inspection and maintenance activities. Please select one of the following options: } & \multirow{4}{*}{1.59} \\
\hline & & 1 None & 0 & 0 & \\
\hline & & 2 Regular inspection of water fixture and plumbing system & 23.23 & 23.23 & \\
\hline & & $\begin{array}{l}3 \text { Regular inspection and maintenance on water fixture and } \\
\text { plumbing system }\end{array}$ & 38.29 & 0 & \\
\hline & \multirow[t]{7}{*}{$\begin{array}{|ll|}5 & \text { Water App liances } \\
& \text { Efficiency }(19.60 \%)\end{array}$} & \multicolumn{3}{|c|}{$\begin{array}{l}1 \text { Percentage of water-efficient appliance usage compared to the total water appliances in } \\
\text { campus. Please select one of the following options: }\end{array}$} & \multirow{6}{*}{8.29} \\
\hline & & - Less than $75 \%$ & 0 & 0 & \\
\hline & & $-75-84 \%$ & 75 & 75 & \\
\hline & & $-85-94 \%$ & 85 & 0 & \\
\hline & & $-95-99 \%$ & 95 & 0 & \\
\hline & & $-100 \%$ & 100 & 0 & \\
\hline & & 2 Use of automatic sensor water taps (if any) - Bonus Point & 100 & 0 & 0.00 \\
\hline & \multirow{3}{*}{$\begin{array}{l}6 \text { Alternative/Recycled Water } \\
\text { Resources }(26.90 \%)\end{array}$} & \multicolumn{3}{|l|}{ Please select one or more from the following options: } & \multirow{3}{*}{0.00} \\
\hline & & 1 Alternative/recycled water is used for garden sprinkler system & 20.72 & 0 & \\
\hline & & 2 Alternative/recycled water is used for toilet flushing & 79.28 & 0 & \\
\hline \multirow{5}{*}{$\begin{array}{l}\text { Wastewater } \\
\text { Treatment (WT) } \\
20.15 \%\end{array}$} & \multirow{5}{*}{$\begin{array}{l}\text { Wastewater Management } \\
\text { Authority }(100 \%)\end{array}$} & Please select one of the following options: & & & \multirow{5}{*}{4.10} \\
\hline & & 1 None & 0 & 0 & \\
\hline & & 2 Processed and handled by a third party & 20.37 & 20.37 & \\
\hline & & 3 Processed and handled completely by the campus & 32.85 & 0 & \\
\hline & & 4 Processed and handled by campus and partly by a third party & 46.78 & 0 & \\
\hline \multirow[t]{2}{*}{$\begin{array}{l}\text { Water Quality } \\
\text { (WQ) } \\
23.45 \%\end{array}$} & $\begin{array}{l}1 \text { Non-potable Water } \\
(100 \%)\end{array}$ & $\begin{array}{l}\text { Conduct proper test according to the laws/regulations, and able to } \\
\text { provide laboratory test results when water sources comes from } \\
\text { water utility, e.g. PDAM (Indonesian regional utility } \\
\text { company)/public water/ground water/water treatment installation }\end{array}$ & 100 & 100 & 23.45 \\
\hline & $\begin{array}{l}2 \text { Potable Water (if any) - } \\
\text { Bonus Point }(100 \%)\end{array}$ & $\begin{array}{l}\text { Conduct proper test according to the laws/regulations, and able to } \\
\text { provide laboratory test results for only potable water }\end{array}$ & 100 & 100 & 23.45 \\
\hline \multicolumn{5}{|c|}{ Total Score } & 82.21 \\
\hline
\end{tabular}

\section{Conclusions}

The new standard of green campus assessment on water issues has been successfully developed under the name Water Security (WS) category. The weight and scoring system of each subcategory, indicators and sub-indicators are included so that this standard can be used by higher education institutions around the world. Compared with UI GreenMetric, this new category, with 3 subcategories, 8 indicators and 4 sub-indicators, is more comprehensive in measuring the performance of green practices done by a campus. This Water Security (WS) category is expected to be a recommendation for Universitas Indonesia to update the UI GreenMetric for maximum sustainability, both locally and globally.
This green campus assessment standard has also proved to be well used in a case study at Universitas Katolik Parahyangan. Unpar scored 82.21 points out of a total of 122 points, indicating that its green performance was at Good category. The score was then used as a reference in determining improvement strategies in accordance with Unpar's vision and mission. The proposed strategies include an increase of water security campaign for students and staff using various media, especially in the form of consequence/fear appeals, reuse of rainwater harvesting, an area extension for water conservation practices, addition of water meters in each building, and improvement of quantity and quality of regular inspections, monitoring, and evaluation on water appliances/installation in campus area. 
This work was supported in part by the Directorate General of Higher Education, Republic of Indonesia under Excellence Higher Education Institution Research (PUPT) grants scheme 2016. The authors are immensely grateful to Universitas Katolik Parahyangan and Institut Teknologi Nasional for their continuous supports.

\section{References}

1. National Geographic, Freshwater Crisis (2018). Available at: https://www.nationalgeographic.com/environment/fre shwater/freshwater-crisis/

2. Environmental Protection Agency, All the Water in the World: Magnificent Ground Water Connection (2015). Available at: https://www.epa.gov/sites/production/files/201508/documents/mgwc-ww-intro.pdf

3. United Nations, Water Scarcity (2018). Available at: http://www.unwater.org/water-facts/scarcity/

4. UNESCO, $4^{\text {th }}$ Edition of the UNI World Water Development Report (WWDR4) (2012). Available at: http://www.unesco.org/new/en/naturalsciences/environment/water/wwap/wwdr/wwdr42012/

5. M Wimala, E Akmalah, I Irawati, and M R Sururi, Overcoming the Obstacles to Green Campus Implementation in Indonesia. J. of Civil,
Environmental, Structural, Construction and Architectural Engineering 1010 1352-1357 (2016). Available at: http://waset.org/publications/10006091/overcomingthe-obstacles-to-green-campus-implementation-inindonesia

6. Universitas Indonesia, Guideline of UI GreenMetric World University Ranking 2016 (2016). Available at: http://greenmetric.ui.ac.id/wpcontent/uploads/2015/07/UI-Greenmetric-Guideline2016.pdf

7. Media Indonesia, UI and ITS, the Best Green Campus (in Indonesian) (2016). Available at: http://www.mediaindonesia.com/index.php/news/read /85174/ui-dan-its-kampus-hijau-terbaik/2016-12-30

8. Universitas Indonesia, UI GreenMetric World University Ranking. Job International Stakeholder Workshop (JISW) UI-UF-UC: Novel Approaches of Employing Green Infrastructure to Enhance Urban Sustainability (2015). Available at: http://ggi.dcp.ufl.edu/_library/files/Presentation\%20D ay\%203/UI\%20GreenMetric-JISW.pdf

9. AASHE, STARS Technical Manual ver. 2.1. (2017). Available manual.html 